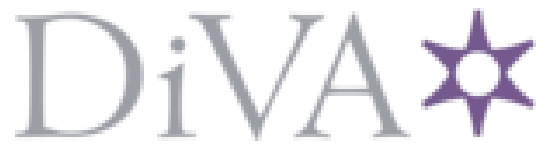

http://www.diva-portal.org

This is the published version of a chapter published in Nordic Mediation Research.

Citation for the original published chapter:

Jacobsson, M., Wahlin, L., Fromholz, E. (2018)

Victim offender mediation in Sweden: an activity falling apart?

In: Anna Nylund, Kaijus Ervasti, Lin Adrian (ed.), Nordic Mediation Research (pp. 67-79).

https://doi.org/10.1007/978-3-319-73019-6_5

N.B. When citing this work, cite the original published chapter.

Permanent link to this version:

http://urn.kb.se/resolve?urn=urn:nbn:se:umu:diva-146328 


\title{
Victim Offender Mediation in Sweden: An Activity Falling Apart?
}

\author{
Maritha Jacobsson, Lottie Wahlin, and Eva Fromholz
}

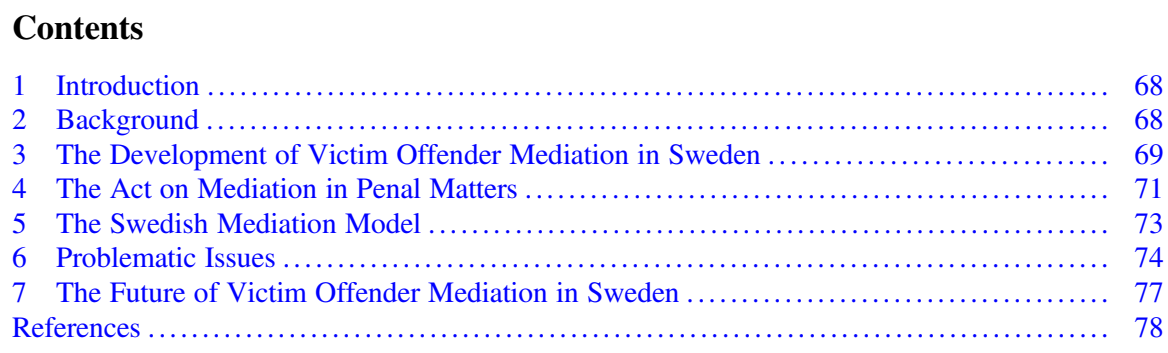

\begin{abstract}
In Sweden, the government has invested considerable resources to implement victim offender mediation (VOM) for young people (under the age of 21). Despite this, the number of mediations is decreasing. What appears to be a gap between the legislator's intentions and practical applications raises questions about the reasons for this gap and the premises for mediation in penal matters in Sweden today. Our purpose in this article is to highlight and discuss some circumstances that can explain this decrease and the future of VOM in Sweden. We start by discussing the development of VOM in Sweden and continue by analysing possible reasons for why mediation is declining. The conclusion is that the decrease can be explained by problems related to legal and organisational structures as well as mediation practice. The conclusion is also that if the state and municipalities do not show more interest in VOM and restorative justice, then this activity will probably disappear.
\end{abstract}

\author{
M. Jacobsson ( $₫)$ \\ Department of Social Work, Umeå University, Umeå, Sweden \\ e-mail: maritha.jacobsson@umu.se \\ L. Wahlin \\ Institute for Mediation Training in Sweden, Stockholm, Sweden \\ e-mail: info@medlarutbildning.com \\ E. Fromholz \\ Department of Social Work, Stockholm University, Stockholm, Sweden \\ e-mail: eva.fromholz@socarb.su.se
}




\section{Introduction}

In Sweden, the government has altogether spent 66 million SEK (approximately EUR 6.4 million) between 2003 and 2007 to implement victim offender mediation (VOM) for young people (under the age of 21). In 2002, a new act concerning VOM, the Act on Mediation in Penal Matters (Lag 2002:445 om medling med anledning av brott) was introduced (hereafter, the Mediation Act). Furthermore, in 2007, there was a new provision introduced in Chapter 5, section 1c of the Swedish Social Services Act (Socialtjänstlag 2001:453) according to which it is mandatory for municipalities to offer mediation. Accordingly, the Swedish government has invested considerable resources to implement VOM in Sweden. Despite this, the number of mediations is decreasing (Wahlin and Jacobsson 2017). What appears to be a gap between the legislator's intentions and practical applications raises questions about the reasons for this gap and the premises for mediation in Sweden today. Our purpose in this article is to highlight and discuss some circumstances that can explain the decrease of mediation in penal matters and the future of VOM in Sweden.

After this introduction, we will give you a background and description of the development of VOM in Sweden. We will thereafter provide a brief description of the Swedish Mediation Act and the premises that it builds upon. In the following part, we will describe the mediation model that is mainly used in Sweden. Thereafter follows a discussion where we will highlight some problems that can have significance for the decreased use of mediation in penal matters in Sweden today. Finally, we will discuss the future of VOM in Sweden.

\section{Background}

Courts and social service authorities have common goals in preventing children and young people from committing crimes. In order to do that they use different means. In the Social Services Act (Socialtjänstlag 2001:453) Chapter 1, section 2 and Chapter 5, as well as in The Care of Young Persons Special Provisions Act (Lag 1990:52 med särskilda bestämmelser om vård av unga) in Chapter 1, section 2-3, emphasis is placed on the best interests of the child and the child's future development, in other words, prognostic assessments becomes central (Hollander 1985). Criminal law focuses instead on retributive values such as punishment, and discomfort, judgments made retrospectively based on a crime event (Edvall Malm 2012; Tärnfalk 2014). Hence, the social service authorities and courts share the same goals, but the means differ.

Also in VOM it is a goal to prevent children and young people from committing crimes. Furthermore, emphasis is placed on the best interests of the child and the child's future development, while in this case, the means are based on restorative values (Restorative justice, RJ), which means that emphasis is put on the involvement and welfare of both parties in the process following the offense (Zehr 2002). In Sweden, however, VOM is complementary to the trial (see description of the 
regulation below). It means that those involved have to deal with two different value systems.

In retributive justice, the focus is retrospective (Zehr 2002):

1. The crime: what laws has been broken?

2. The question of guilt.

3. The punishment.

The State is the main protagonist, and the emotional and moral aspects of those affected are left aside.

The restorative justice system is, in the same way, as the social service authorities, more concerned with prognostic values (Zehr 2002):

1. The parties: who has suffered damage and who has caused the damage?

2. The victim's needs.

3. The offender's responsibility to repair the damage.

Within the international movement for restorative justice, there has been a debate concerning contradictions existing between restorative and retributive values (Johnstone 2003). Some advocates of restorative justice believe this perspective should be the normal way to react to crime and that the legal processes only should be considered if the reparative processes have failed. Others claim that it is possible to combine both systems. Braithwaite and Zehr have, since the mid-1980s, argued for a strong dividing line between the retributive justice and the reparative systems (Braithwaite 1999; Zehr 1990). Later, Zehr (2002) changed his mind in some aspects, thinking that the two systems have a lot in common. For example, crime creates an imbalance between the victim and the offender; the victim can ask for compensation and the offender has obligations. He also claims that it is important to have a system that can deal with offenders who deny their responsibility. When the legal system is working at its best, it has essential qualities according to Zehr: respect for law and order, efficient processes and consideration of human rights. However, Zehr (1990, 2002) argues we should seek reparative processes as far as possible.

\section{The Development of Victim Offender Mediation in Sweden}

The interest in VOM was awakened in the late 1980s when some activities sporadically emerged in Hudiksvall by the police and in Solna/Sundbyberg by the social services authorities. In 1997, the National Council of Crime Prevention (Brottsförbyggande rådet, BRÅ) received a government mission to start pilot projects concerning mediation in penal matters with young offenders in the Swedish municipalities. ${ }^{1}$ The evaluation from the pilot projects showed good results in terms of satisfaction (SOU 2000:105, Brottsförebyggande rådet 1999:14, 2000:8).

\footnotetext{
${ }^{1}$ Lottie Wahlin worked at BRA 1999-2007 with these issues.
} 
According to BRA, mediation should be organised within the framework of municipal social services, but disconnected from the other social services activities. They were also of the opinion that there should be a clear regulatory framework for police and prosecutors on how mediation issues should be handled. BRÅ's opinion were not based on experiences from other countries, but they were aware of a need for knowledge development and education on how to organise VOM.

The issue of VOM was further investigated in a government commission (SOU 2000:105). A framework legislation was suggested, which means that the law allows extensive scope for assessing the circumstances in each case. The commission's proposal was based on the opinion that there was too little knowledge about mediation and that it, therefore, should not be taken into account in the legal process. Also, the commission would not introduce mediation as a penalty, given that it based on voluntary involvement of the victims. Nor would it be possible with conditional allegations, since there was a risk that the perpetrators in such case would participate for "wrong" reasons, such as in order to get lighter punishment.

Instead, the commission shared BRÅ's assessment that VOM should be organised within the municipal social services. They did not, however, want to make any detailed regulations, as municipalities were assumed to have different conditions, depending on for example size and economy. Voluntary participation in mediation was emphasised and it was considered important that the parties really should be informed about that. To avoid that mediation would get the character of a minor trial the perpetrator should have acknowledged at least participation in crime.

The commission also considered that there was a need for a co-ordinating national unit that would be responsible for education, quality assurance and method development. However, The National Board of Health and Welfare (Socialstyrelsen-a national co-ordinating unit) considered in their reply that mediation is one of several methods social services can use to support both offenders and victims and that it, therefore, should be a part of the usual social services activities.

As described, in 2002, the new Act on Mediation in Penal Matters was introduced, based on the proposal by the government commission. At the same time, the government instructed BRA to allocate financial resources and provide training, methodology and quality assurance.

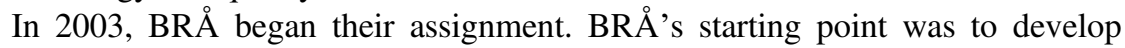
methodologies and quality assurance by creating so-called model municipalities and regional co-ordinators who could assist and support other municipalities in the practical mediation work.

In December 31, 2007, BR ̊ completed their mission of VOM. The government's idea now was that mediation should "stand on its own feet". During the assignment, four different reports had been written (Brottsförebyggande rådet 2005:14, 2007, 2008a,b). Experience is summarised in some important issues, such as the need for skilled and educated mediators, earmarked time for mediation, well-functioning routines and co-operation with various partners for effective mediation. The final report (Brottsförebyggande rådet 2008a) presented three different ways to organise mediation. The first proposal had an organisational structure, with an overall national co-ordinator, regional co-ordinator at the county level and finally municipal 
mediation organisations that should handle the practical activities. This organisation was inspired by the Norwegian model, National Mediation Services (Konfliktråd). The other proposal was based on municipal co-operation in regional networks, while the third was based on municipal co-operation in which one of the municipalities was responsible for co-ordination. The organisation that was used in practice was the second one, where each municipality is responsible for how mediation activities are organised.

In summary, the Swedish government has put great effort to build an effective and nationwide mediation activity, which could indicate that they want to strengthen prognostic values. Despite this, the number of mediations are decreasing and the interest in mediations seems to have reached a point of stagnation. There are no national statistics on VOM in Sweden, but there are other studies. There are a total of 290 municipalities in Sweden. When BRA conducted their review in 2008, they got answers from 287 of them, and 252 stated that they offered mediation to varying degrees. In studies made by Jacobsson et al. (2012, 2013) conducted in 2008-2010, they received questionnaires from 109 mediation co-ordinators responsible for mediation in a total of 212 municipalities. According to a more recent study (spring 2015-spring 2016) (Wahlin and Jacobsson 2017), 181 municipalities offered mediation. When interviews were conducted with the mediation officers in this study, they also told that they had fewer mediation cases compared to previous years. That indicates that the interest in mediation has substantially decreased.

\section{The Act on Mediation in Penal Matters}

The formulation of the act can have significance on how the relations between retributive and restorative values is perceived by, for example, the police, prosecutors, judges and mediators. As suggested by the government commission, the act is constructed as a framework legislation. It comprises ten sections.

According to the first section, the state or a municipality should organise mediation (section 1). The aim is that the plaintiff and offender, with help from a mediator, meet in mediation to talk about the crime event and its consequences (section 2). As it appears from the preparatory work, mediation is complementary to the criminal proceedings (see i.e. prop. 2001/02:126). Furthermore, mediation should benefit both parties in order to reduce harm from the crime event (section 3). According to the same section, mediation shall aim at the perpetrator gaining greater insight into the consequences of the crime and that the plaintiff is given the opportunity to process the experiences of the crime.

Furthermore, it is regulated in the act that the mediator should be a competent and upright person and impartial in regard to the parties (section 4). The mediator can either be a layman or a professional, but it is not clear from the law or the preparatory work what it means to be a competent and upright person, in this context. There is a discussion in the government bill about formalising the requirements, but the government was of the opinion that it would be sufficient that it appears from the 
law that it is the mediator's personal qualities, education and experience that should be decisive for the appointment as a mediator, and that the mediator thus "should be competent and otherwise suitable for the task" (our translation) (prop. 2001/02:126).

Mediation should be voluntary for both parties (section 5). According to the same section, the crime has to be reported to the police and the offender must have acknowledged the act or involvement in it. In the case of offenders below the age of 12, mediation shall only take place if there are special reasons. In the case of the plaintiff, no age is specified. According to the preparatory work, the victim should have achieved a sufficient age and maturity for mediation to take place (prop. 2001/ 02:126).

The mediation should be carried out promptly (section 6). It is also stated in this section that the mediator shall consult the investigator if a mediation is intended to take place before the preliminary investigation has been completed. If mediation is meant to take place thereafter, but before there is a statutory verdict, the mediator shall consult with the prosecutor.

Both the offender and the plaintiff should be informed about and prepared for the mediation process (section 7). Furthermore, the parents and legal guardians of both parties should have the opportunity to take part in the mediation meeting if there are no particular reasons against it (section 8). If this is not possible, it may be a circumstance that makes mediation inappropriate (cf. Sect. 5, above), especially if it is a child under the age of 15 (prop. 2001/02:126). Furthermore, according to the same section, there may be other people who can act as support persons to both parties if it is consistent with the purpose of the mediation and appropriate otherwise. It could be, for example, a close relative who is not a custodian, a family parent or other healthcare provider. According to the preparatory work, this must be decided on a case-by-case basis and should not be regulated in law in a binding manner (prop. 2001/02:126).

In the mediation meeting, the plaintiff should be able to tell about the crime experience and its consequences. Moreover, the plaintiff can also make demands for compensation (section 9). According to the same section, the offender should have the opportunity to give his view, tell why the crime was committed and apologize. The last section (section 10) in the act is about agreements concerning compensation. Stated in this section, the mediator shall only assist in the settlement of an agreement if it is clear that the agreement is not unreasonable. According to the preparatory work, the starting point is that the agreement should be reasonable in relation both to the crime committed and to the damage that has occurred. It is also pointed out that it is not always appropriate to deal with the issue of economic compensation in the mediation situation. If the parties disagree about the level of compensation, the question should instead be dealt with in the ordinary legal process, and this is also the case if the question becomes complicated due to the fact that there are several offenders (prop. 2001/02:126). 


\section{The Swedish Mediation Model}

As described, it is the state or a municipality that should organise mediation. In practice, it is only the municipalities. It is most common with a meeting with one mediator, a victim and an offender before the trial (Wahlin and Jacobsson 2017). Most of the mediation offices had professional mediators $(70 \%)$, some had only layman (17\%) and the rest had both officials and laymen (ibid.).

The mediation model that is most common is the process-oriented (Strang and Braithwaite 2001), that was taught by BRÅ (Wahlin and Jacobsson 2017). There is one mediation office that stands out; they are using a transformative mediation model, inspired by Folger and Bush (1996). The characteristic of process-oriented mediation is that the mediation is regarded as a process that begins with the crime event and ends with a possible agreement between the parties. The process begins when a crime is committed and a police report is issued. Someone, generally the police, asks the perpetrator if they are interested in mediation and if a mediator can take contact. If the offender is willing, the case will be conveyed to mediation. The mediator then contacts the offender to try to meet him/her at a pre-meeting. At the pre-meeting the mediator assesses whether the offender has a true will to mediate. The offender is informed of what mediation means, telling the mediator about the crime event, the consequences, feelings, thoughts and other things that may be relevant in the context. In case the offender is interested to mediate the mediator will also take contact with the victim and have a pre-meeting with him/her. This meeting goes on the same way as that of the offender. If both parties are interested to mediate a joint mediation meeting is conducted.

If the meeting is intended to take place before the end of the preliminary investigation, the mediator must consult with the investigator. As described above, the mediator also contacts the prosecutor to inform the offenders willingness to mediate and to ensure that a mediation does not interfere with the legal process (section 6). Normally the mediation takes place before the trial. The mediation meeting most often follow a certain structure; introduction, the victim and thereafter the offender talks about the crime event, questions about the crime event, the victim and thereafter the offender talks about the consequences of the crime, questions about the consequences and, at last, agreements (Jacobsson et al. 2013; Brottsförebyggande rådet 2007).

It has been found that in practical applications mediators often say to the parties that confidentiality applies to all who attend the meeting (Jacobsson et al. 2013), but it is, according to the rules in the applicable law, Chapter 2, section 1, and Chapter 35, section 14, thirteenth section, of the Act on Publicity and Confidentiality (Offentlighets- och sekretesslagen 2009:400), only the mediators who are covered. It is also unclear how much information mediators can convey to the investigators and prosecutors. According to the rules, it should be sparingly.

As been described, parents and legal guardians should have the opportunity to take part in the mediation meeting if there are not reasons against it (section 8). In practice, it is the mediator who decides whether or not other persons will attend in 
the mediation meeting (Socialstyrelsen 2009). According to a study by Wahlin and Jacobsson (2017), mediators evaluate this differently. Some mediators believe that it is positive that parents or other actors are present, while others believe they may be interfering with the process, for example, by acting aggressively or trying to take control of the meeting.

\section{Problematic Issues}

What appears to be a gap between the legislator's intentions and practical applications raise questions about the reasons for this gap and the premises for mediation in Sweden today. In this part of the article, we will highlight and discuss some circumstances that can explain the decreased use of mediation in penal matters in Sweden.

The problems that we have identified is related to both law and practice. To begin with, it seems the formal technical construction of the legislation in which the act is constructed as a framework legislation, with many circumstances being unregulated or left to the practitioners to solve with little guidance in the preparatory work, is problematic (see also Marklund 2011).

One problem with the law is that there are no formal requirements concerning the mediator. This is not in line with the Council of Europe Recommendation No $\mathrm{R}$ (99) 19, which clearly emphasises that mediators are in need of education and support. As described, according to the Mediation Act, a mediator can either be a layman or a professional as long as the mediator is a competent and upright person, but it is not clear from the law or the preparatory work what it means to be a competent and upright person. In practice, this can be a problem since the mediators often work alone, without the opportunity to exchange experiences and knowledge with other mediators and educators (Wahlin and Jacobsson 2017).

Another problem is that parents and legal guardians should, according to the law, have the opportunity to take part in the mediation meeting if there are not reasons against it. Neither is this regulated in detail in law and preparatory work. As described above, in practice, it is the mediator who will decide whether or not other persons will attend in the mediation meeting, and mediators evaluate this differently. Some mediators believe that it is positive that parents or other actors are present, while others mean that they may be interfering with the process, for example, by acting aggressively or try to take control of the meeting (Wahlin and Jacobsson 2017).

A third problem is about agreements and compensations. There are big differences between restorative and retributive systems in relation to this subject. According to restorative values, the parties themselves should agree on what has to be compensated, how much and in which way it should be done. It is not explicitly formulated in the Mediation Act, nor in the preparatory work, what is meant by "agreements". In practice, the agreement can be made written or spoken. Moreover, it may concern economic compensation, compensation through work or future 
behaviour between the parties. In our present and previous research, we have found that the attitudes to agreements varies a lot among mediators in the municipalities (Jacobsson et al. 2013; Wahlin and Jacobsson 2017). It is, for example, possible that the offender experiences double punishment if $s / h e$ has agreed to give economic compensation during mediation, and later on, at the trial process, is ordered to pay damages by the court. It is also possible that the offender gets a more lenient punishment (see below).

A broken agreement can have negative economic consequences for the victim, as well as emotional, since it can be a sign that the offender's regret was not real. If the victim wants to go on with the process, s/he can sue the offender in a civil process (Socialstyrelsen 2012; Brottsförebyggande rådet 2007). The mediator has no duty to follow-up the agreement. The fact that an agreement is not fulfilled, can, however, have legal effects, in a civil process as well as in a criminal process. The prosecutor should, therefore, at least in some cases, get a notification of how the agreement has been completed. In practice, mediators deal with this issue in different ways, some mediators always announce this, others sometimes or never (Wahlin and Jacobsson 2017). Hence, if it has come to the mediator's knowing that the offender has not fulfilled his commitment, the mediator shall inform the prosecutor, unless it is unnecessary (prop. 2001/02:126).

A fourth problem is if and in such case how the offender's willingness to mediate should be taken into account. As been described, in Sweden mediation is complementary to the criminal proceedings, i.e. that it is possible to influence the retributive system with restorative values, but mediation could also be seen as an alternative punishment or as an alternative to punishment (Daly 2000). This is due to the fact that the prosecutor should, according to section 17 of the Young Offenders Special Provisions Act (Lag 1964:167 med särskilda bestämmelser om unga lagöverträdere), take the offender's willingness to mediate into account when deciding whether to prosecute or not. Also, according to Chapter 29, section 5 of the Penal Code (Brottsbalk 1962:700), the court can take mediation into account in their choice of sentence. It seems to be a problem also that the application of these rules differs. Mediators in a study (Wahlin and Jacobsson 2017) claimed that the police did not refer cases to the mediation offices, because they believed that offenders should be punished by the state and that their will to mediate could lead to a milder or no punishment. As far as we know (see also Jacobsson et al. 2013; Socialstyrelsen 2012), it is, however, uncommon that prosecutors take the offender's will to participate in mediation into account when they determine the sentence, but this differs - some prosecutors often take this into account, while others do not (ibid.). In other words, young offenders have different possibilities to get lower penalty in the criminal proceeding.

A fifth problem is that, according to the mediators, many of the offenders did not want to confess (Wahlin and Jacobsson 2017). As described above, according to the fifth and sixth sections in the Mediation Act, the suspects must have acknowledged the act, or at least involvement in it, and the mediation should be implemented as soon as possible-in practice before trial. This stands in contrast to rule of law principles and international standards, for example, article 11(1) of the Universal 
Declaration of Human Rights (UN), according to which: "Everyone charged with a penal offence has the right to be presumed innocent until proved guilty according to law in a public trial at which he has had all the guarantees necessary for his defense". The fact that the laws are interpreted differently by mediators, police officers, prosecutors and judges contributes to legal uncertainty for young offenders. Mediation can be considered as a complement to trial or punishment, as an alternative to punishment or as an alternative punishment. There is no common legal strategy. It is, instead, up to individual professionals to assess.

It is not only the formal technical construction of the legislation that the act is constructed as a framework legislation that is problematic, there are also organisational problems. As described, since 2008, all municipalities are under the obligation to offer mediation to offenders below the age of 21 . As also have been described, there are, however, a large variation in mediation activity among municipalities. The municipalities are free to organise mediation their own way. Some municipalities have mediation offices, others buy these services from other municipalities, and some do not have any mediation services at all (Wahlin and Jacobsson 2017). There are also differences between mediation offices, i.e. how they co-operate with other organisations. Some municipalities have given priority for mediation. They have mediators working full time and special mediation training programmes. Their mediators have time to create well-functioning activities, and co-operation with authorities, like the police, the social services, prosecutors and probation offices. In other municipalities, social workers mediate as a part of their employment schedule. Other municipalities recruit laymen mediators when needed (ibid.).

This means that several offenders, and victims as well, are not getting the chance to mediate at all. This causes legal uncertainty.

One of the main reasons can be the absence of a national co-ordinator. This is something that has been brought to discussion. In the government commission (SOU 2000:105) that preceded the Mediation Act, there was a proposal that the National Board of Health and Welfare should be a national co-ordination unit and responsible for training, quality assurance and methodology development. But the National Board of Health and Welfare considered that mediation is just one of several methods social services can use to support offenders and victims and that it, therefore, should be included in the regular social services activities. Despite this fact, the Swedish government gave the National Board of Health and Welfare the task to be a supervisory authority, a mission that was reluctantly accepted. In 2012, the National Board of Health and Welfare made a review of the mediation services in Sweden. In their report, they concluded that mediation does not work as conceived and that there was a need for a co-ordinator at a national level. This was a statement that BRÅ already made when they ended their government assignment 4 years earlier. The National Board of Health and Welfare also underscored a lack of knowledge about mediation in the judiciary, and a climate of distrust reigning. In June 2013, the National Board of Health and Welfare's responsibilities concerning mediation were replaced by the Health and Social Care Inspectorate (Inspektionen för vård och omsorg, IVO). The IVO's responsibility is mainly to follow-up and check notifications and exercise risk analysis. When it comes to mediation, nothing 
has been done at all. This may be because the inspectorate has not received any notifications or because of their priorities. In conclusion, there is no overarching authority responsible for VOM in Sweden today. Instead, it is up to the municipalities to decide how they want to give priority to these activities.

\section{The Future of Victim Offender Mediation in Sweden}

We have in this article highlighted and discussed some circumstances that can explain why the interest in VOM is decreasing in Sweden. In addition to these issues, there are also other problems. Earlier studies have shown that criminal policy concerning young people in Sweden today mainly is about more control and more recourses to the police (Edvall Malm 2012). Our conclusion is as follows: if the state and municipalities do not change their criminal policy and show more interest in VOM and restorative justice, then this activity will probably disappear. But if the state would show more interest in VOM and wants to develop these activities, then there are some issues to consider.

Since Norway, Finland and Denmark have seemingly well-functioning mediation organisations, it would be possible to find inspiration from them, both when it comes to legislation and how to organise VOM on different levels. These countries, unlike Sweden, have national and regional co-ordinators. One important issue to consider is if and, if so how, another type of organisation in Sweden can support the quality and development of VOM.

Another issue to consider, in relation to experiences from other countries, is if VOM should be regarded as a complement to the traditional legal system or as an alternative punishment or an alternative to punishment. In Norway, for example, the intention is that mediation should be an alternative to punishment used in less serious crimes (Larsson and Dullum 2001). This is also an ideological question that can be discussed in relation to rule of law principles and international standards.

Another important issue is when and in which crimes mediation should be present. According to our study (Wahlin and Jacobsson 2017), many of the mediation offices in Sweden do not mediate in cases with more severe offenses because of statements in the government bill (prop. 2001/2002:126). However, we should add that there are restorative advocates claiming that mediation works best in more serious crimes (see, for example, Strang et al. 2013), and several countries have developed such kind of mediation. In Denmark, for example, a report on restorative justice and sexual violence was published as a project funded by the European commission (Mercer and Sten Madsen 2015). Furthermore, a recently published anthology discussed legal and therapeutic aspects (Zinsstag and Keenan 2017). We are not proposing that mediation in sexual offences or in more serious crimes is something to be recommended, but we welcome a serious debate about when and how it is most adequate with VOM in Sweden and the importance to get both further knowledge and inspiration from other countries that have more experience. 


\section{References}

Braithwaite J (1999) Restorative justice: assessing optimistic and pessimistic accounts. In: Tonry M (ed) Crime and justice: a review of research, vol 25. Chicago University Press, Chicago, pp $1-127$

Brottsförebyggande rådet (1999) Rapport 1999:14 Medling vid brott - gärningsmännen berättar. Brottsförebyggande rådet information och förlag, Stockholm

Brottsförebyggande rådet (2000) BRÅ rapport 2000:2 Medling vid brott - brottsoffren berättar. Brottsförebyggande rådet information och förlag, Stockholm

Brottsförebyggande rådet (2005) Rapport 2005:14. Medling vid brott i Sverige på 2000-talet. Brottsförebyggande rådet information och förlag, Stockholm

Brottsförebyggande rådet (2007) Medling vid brott. En handbok. Brottsförebyggande rådet information och förlag, Stockholm

Brottsförebyggande rådet (2008a) Medlingsverksamhetens utbredning. Brottsförebyggande rådet information och förlag, Stockholm

Brottsförebyggande rådet (2008b) Medling i går, i dag och i morgon. En kort skrift om medling vid brott, Nätrapport

Council of Europe (1999) Recommendation No. R (99) 19 of the Commitee of Ministers to Member States Concerning Mediation in Penal Matters

Daly K (2000) Revisiting the relationship between retributive and restorative justice. In: Strang H, Braithwaite J (eds) Restorative justice: philosophy to practice. Ashgate/Darmouth Publishing, Aldershot, pp 33-54

Edvall Malm D (2012) Det socio-polisiära handlingsnätet. Om kopplingar mellan polis och socialtjänst kring ungdomars kriminalitet och missbuk. Doctoral dissertation, Umeå University, Umeå

Folger JP, Bush RAB (1996) Transformative mediation and third-party intervention: ten hallmarks of a transformative approach to practice. Conflict Resolut Q 13(4):263-278

Hollander A (1985) Omhändertagande av barn. En studie av baranavårdsmål i förvaltningsdomstolarna 1974, 1977 och 1982. Aktuell juridik förlag, Stockholm

Johnstone, G. (Ed.). (2003). A restorative justice reader: Texts, sources, context (pp. 1-18). Willan Publishing, Devon

Jacobsson M, Wahlin L, Andersson T (2012) Victim-offender mediation in Sweden: is the victim better off? Int Rev Victimol 18(3):229-250

Jacobsson, M., Wahlin, L., \& Andersson, T. (2013). Den svenska medlingsmodellen: till nytta för brottsoffret?. Gleerups Utbildning AB.

Larsson P, Dullum J (2001) Fra samfunnstjeneste til samfunnsstraff. Utviklingen i bruken av samfunnsstraffer og konfliktråd i Norge. Nordisk Tidsskrift for Kriminalvidenskab 88 (2):154-168

Marklund L (2011) Ett brott - två processer: Medling vid brott och unga lagöverträdare i straffprocessen. Uppsala universitetstryckeri. Doctoral Dissertation, Uppsala University

Mercer V, Sten Madsen K (2015) Doing restorative justice in cases of sexual violence. A practical guide. In: Keenan M, Zinsstag E (eds) Daphne 2011 JUST/2011/DAP/AG/3350. University of Leuven, Leuven

Prop. 2001/2002:126. Medling med anledning av brott

SOU 2000:105. Medling vid ungdomsbrott

Strang H, Braithwaite J (eds) (2001) Restorative justice and civil society. Cambridge University Press, Cambridge

Strang H, Sherman LW, Mayo-Wilson E, Woods D, Ariel B, Strang H (2013) Restorative Justice Conferencing (RJC) using face-to-face meetings of a systematic review. Campbell Syst Rev 12

Tärnfalk M (2014) Professionella yttranden: en introduktion till socualt arbete med unga överträdare. Natur \& Kultur, Stockholm

Socialstyrelsen (2009) Barn och unga som begår brott. En handbok. Socialstyrelsen, Stockholm

Socialstyrelsen (2012) Medling vid brott avseende unga lagöverträdare. Socialstyrelsen, Stockholm 
Wahlin L Jacobsson M (2017) Medling vid brott. En enhetlig svensk modell? Report: Allmänna Barnahuset

Zehr H (1990) Changing lenses: a new focus for crime and justice. Herald Press, Scottdale

Zehr H (2002) The little book of restorative justice. Good Books, Intercourse

Zinsstag E, Keenan M (2017) Restorative responses to sexual violence: legal, social and therapeutic dimensions. Routledge, London and New York

Open Access This chapter is licensed under the terms of the Creative Commons Attribution 4.0 International License (http://creativecommons.org/licenses/by/4.0/), which permits use, sharing, adaptation, distribution and reproduction in any medium or format, as long as you give appropriate credit to the original author(s) and the source, provide a link to the Creative Commons license and indicate if changes were made.

The images or other third party material in this chapter are included in the chapter's Creative Commons license, unless indicated otherwise in a credit line to the material. If material is not included in the chapter's Creative Commons license and your intended use is not permitted by statutory regulation or exceeds the permitted use, you will need to obtain permission directly from the copyright holder. 